\title{
INFLUENCE OF AUSFERRITE MICROSTRUCTURE DECOMPOSITION ON THE CORROSION PROPERTIES OF AUSTEMPERED DUCTILE IRON
}

\author{
VPLIV RAZPADA AUSFERITNE MIKROSTRUKTURE NA \\ KOROZIJSKE LASTNOSTI AUSTEMPRANE DUKTILNE \\ NODULARNE SIVE LITINE
}

\section{Sehzudin Dervisic ${ }^{1}$, Hasan Avdusinovic ${ }^{2 *}$, Almaida Gigovic-Gekic ${ }^{2}$, Dejana Kasapović ${ }^{2}$, Sead Pašić ${ }^{1}$}

${ }^{1}$ Faculty of Mechanical Engineering, Matice hrvatske b.b, Mostar 88000, Bosnia and Herzegovina ${ }^{2}$ Faculty of Metallurgy and Technology, Travnička cesta 1, 72000 Zenica, Bosnia and Herzegovina

Prejem rokopisa - received: 2019-09-18; sprejem za objavo - accepted for publication: 2019-12-23

doi:10.17222/mit. 2019.224

\begin{abstract}
Austempered ductile iron (ADI) belongs to the heat-treated class of ductile iron. The heat treatment consists of austenitization and the tempering process. The microstructure of an ADI sample is ausferrite consisting of acicular ferrite, carbon-saturated austenite and a graphite phase in the shape of nodules. The corrosion properties of ADI samples depend on the microstructure constituents and stability of the microstructure. In this paper, the influence of ausferrite microstructure decomposition on the corrosion properties of the ADI samples are presented. During the research, Tafel curve extrapolation and potentiodynamic polarization were used. It was found that the ausferrite microstructure decomposition very strongly affected the general corrosion behavior of the ADI samples.

Keywords: ausferrite, decomposition, general corrosion, austempered ductile iron
\end{abstract}

Duktilna nodularna siva litina izdelana s postopkom "austemperiranja", je posebna vrsta duktilne litine. Austempering (izraz se je udomačil tudi pri nas) je posebna vrsta toplotne obdelave, s katero izboljšamo lastnosti litine. To je postopek, pri katerem so postopki austenitizacije, hitrega ohlajanja in popuščanje, združeni v eno operacijo. Mikrostruktura austemprane litine je sestavljena iz acikularnega (igličastega) ferita, $\mathrm{Z}$ ogljikom nasičenega austenita in grafitne faze $\mathrm{v}$ obliki nodul (kroglic). Korozijske lastnosti takšne litine so odvisne od mikrostrukturnih sestavin in stabilnosti mikrostrukture. V članku avtorji opisujejo vpliv termičnega razpada ausferitne mikrostrukture na korozijske lastnosti litine. Med postopkom raziskovanja so avtorji uporabili Tafelove ekstrapolacijske krivulje in tehniko potenciodinamične polarizacije. Avtorji ugotavljajo, da termični razpad ausferitne mikrostrukture zelo močno vpliva na splošne korozijske lastnosti duktilne nodularne sive litine.

Ključne besede: ausferit, razpad, splošna korozija, austemprana duktilna litina

\section{INTRODUCTION}

Austempered ductile iron (ADI) belongs to the class of ductile iron that exhibits high strength and ductility because of its microstructure being controlled through heat treatment. ADI offers a superior combination of properties. It can be cast like any other type of ductile iron, thus providing all the production advantages of a conventional ductile-iron casting. Subsequently, it is subjected to an austempering process to develop the mechanical properties that are superior to those of the conventional ductile iron, cast and forged aluminum and many cast and forged steels. The mechanical properties of ADI are primarily determined by the metal matrix. The ADI matrix consists of acicular ferrite and carbonstabilized (saturated) austenite, called ausferrite. The austempering process is neither new nor novel and has been utilized since the 1930s on cast and wrought steels. The austempering process was first commercially

*Corresponding author's e-mail:

hasan.avdusinovic@mtf.unze.ba (Hasan Avdusinović) applied to ductile iron in 1972 and its world-wide usage started during 1990s. ${ }^{1}$

Good-quality ductile-iron castings with the following characteristics should be used as the base for an ADI production:

- A consistent chemical composition;

- Castings free of carbides, porosity and inclusions;

- Nodularity $>80 \%$;

Nodule count: a minimum of $100 / \mathrm{mm}^{2}$;

- A consistent metallic-matrix microstructure (the pearlite/ferrite ratio).

ADI covers a group of materials whose mechanical properties can be varied over a wide range by selecting a suitable heat treatment. Figure 1 shows a heat-treatment diagram for the ADI production.

A high austempering temperature $\left(400{ }^{\circ} \mathrm{C}\right)$ allows the production of the ADI with a high ductility, the yield strength in a range of $800 \mathrm{MPa}$, good fatigue and impact strength. A lower transformation temperature $\left(260{ }^{\circ} \mathrm{C}\right)$, results in the ADI with a very high yield strength of 1400 


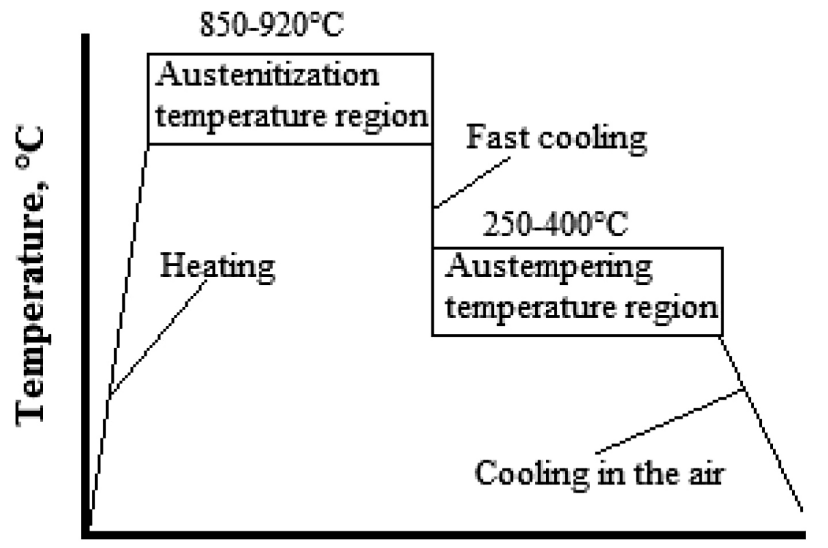

Time, h

Figure 1: Austempering-heat-treatment diagram

MPa or higher, high hardness, excellent wear resistance and contact fatigue strength. Thus, through a relatively simple control of the austempering conditions, ADI can be given a range of properties unequaled by any other material. Like other ductile-iron specifications, ASTM A897 defines the minimum tensile properties for different grades of ADI. ${ }^{2}$ The European standard that defines the austempered-ductile-iron production and properties is EN 1564:1997. ${ }^{3}$

Additionally, as a consequence of the unique properties of ADI such as high strength, fatigue behavior and ductility, ADI has been considered a very up-and-coming engineering material and it is an economical replacement for forged steel, or even aluminum alloys, in several structural applications in the automotive industry (transmission gears, crankshafts, connecting rods), defense industry (aircraft landing gears, cannon shells) and railroad industry. It is important to study the corrosion behavior of this material while it is exposed to acid or chlorine media as the automotive and aircraft parts made of ADI are in continuous contact with such media. R. Rocha-Reséndez et al. ${ }^{4}$ stated that the ADI austempered

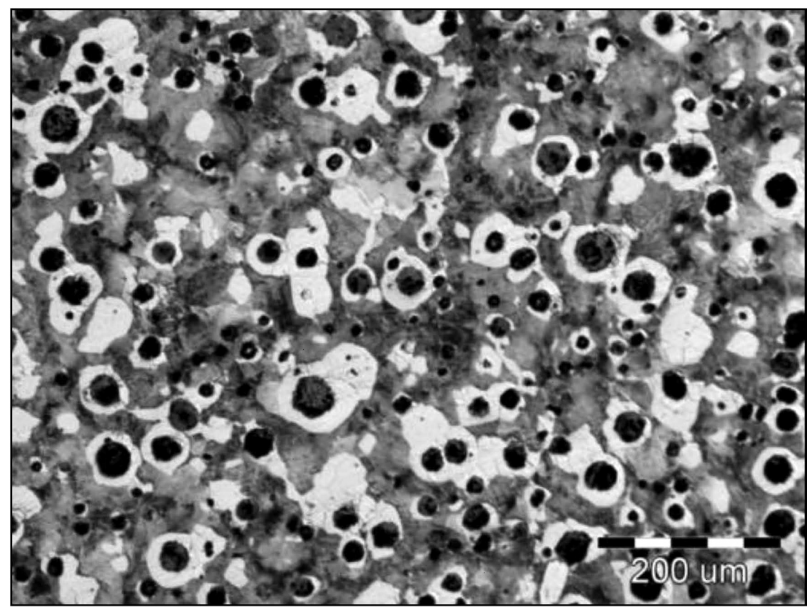

Figure 2: Microstructure of the base ductile iron, 100× mag., Nital etched at a higher temperature showed a better corrosion resistance than the ones austempered at a lower temperature; the complex nature of the corrosion of ADI is influenced by the contents of ferrite and retained austenite; it was also reported that the percentage of retained austenite in ADI influences its corrosion behavior - the higher the percentage of retained austenite, the lower is the corrosion rate Taking into consideration that the corrosion properties depend on microstructure characteristics, the stability of a microstructure during exploitation is very important. The main goal of the investigation described in this paper is to test the general corrosion properties after the ausferrite microstructure decomposition of the ADI samples reheated at different temperatures.

\section{EXPERIMENTAL PART}

\subsection{ADI-sample preparation}

The chemical composition of the base ductile iron used for the ADI samples is presented in Table 1.

Table 1: Chemical composition of the base ductile iron $(w / \%)$

\begin{tabular}{|c|c|c|c|c|c|c|c|}
\hline $\mathrm{C}$ & $\mathrm{Si}$ & $\mathrm{Mn}$ & $\mathrm{P}$ & $\mathrm{S}$ & $\mathrm{Cr}$ & $\mathrm{Cu}$ & $\mathrm{Mg}$ \\
\hline 3.56 & 2.09 & 0.482 & 0.011 & 0.003 & 0.111 & 0.340 & 0.040 \\
\hline
\end{tabular}

The material was poured into U-shape castings. The pearlite-ferrite microstructure of the base ductile iron is presented in Figure 2.

After the cooling of the castings, seven prismatic samples of $15 \times 25 \times 50 \mathrm{~mm}$ were cut and heat treated for the ADI production. The heat-treating procedures were as follows: austenitizing at $870{ }^{\circ} \mathrm{C}$ for $90 \mathrm{~min}$, rapid cooling to the temperature of isothermal transformation $\left(370{ }^{\circ} \mathrm{C}\right)$, holding the samples at the temperature of isothermal transformation for $90 \mathrm{~min}$ in a $\mathrm{KNO}_{3}$ salt bath and cooling them to room temperature in air. The heattreatment diagram for the ADI samples is presented in Figure 3 .

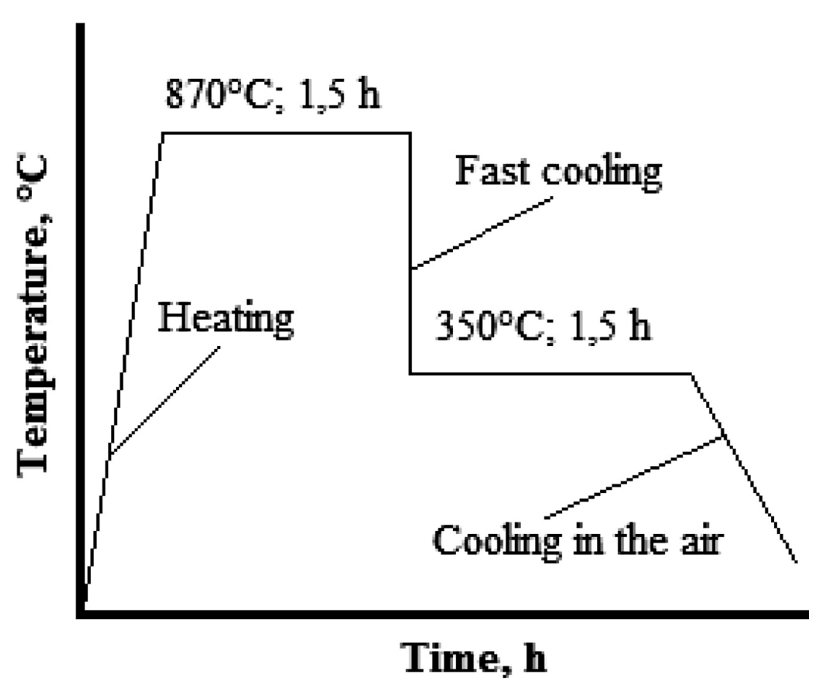

Figure 3: Heat-treatment diagram for the ADI-sample production 


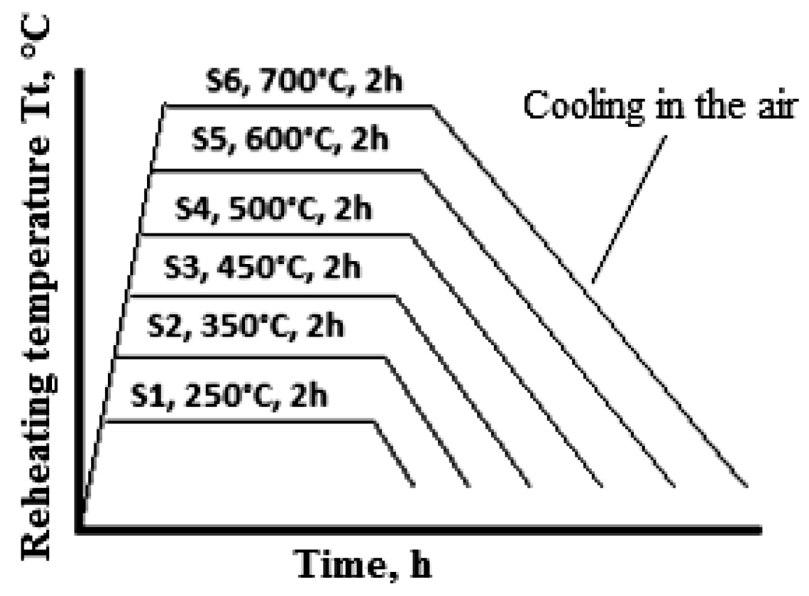

Figure 4: ADI-sample reheating diagram

\subsection{Additional heat treatment of the ADI samples}

In case of additional heat treatment of the ADI samples at an elevated temperature, the decomposition of the ausferrite microstructure occurs. To identify the ausferrite microstructure decomposition during the reheating, six ADI samples were reheated up to the transformation temperature $\left(T_{\mathrm{t}}\right)$ and held at it for $120 \mathrm{~min}$; then the samples were rapidly removed from the furnace and air cooled to room temperature. For the experiment, six different reheating temperatures were preset. The dia- gram of reheating the ADI samples is presented in Figure 4.

\subsection{Test of the corrosion behavior of the ADI samples}

After the additional heat treatment of the ADI samples, corrosion-behavior tests were prepared. Seven samples (the basic ADI sample and six heat treated ADI samples) with $\phi 10 \times 3 \mathrm{~mm}$ were cut. Before the corrosion tests, the preparation of the samples was carried out using grinding paper of different grades. After the grinding, final polishing was carried out, using 0.05 and $0.03-\mu \mathrm{m} \mathrm{Al}_{2} \mathrm{O}_{3}$ water solutions. To test the corrosion rate of the prepared ADI samples, electrochemical techniques involving potentiostatic polarization were used (Tafel curve extrapolation and potentiodynamic-polarization technique). The survey was conducted on a Potentiostat/ Galvanostat, Princeton Applied Research Model 263A-2, using software package PowerCORR®. The samples were treated in a $1 \%$ solution of hydrochloric acid at room temperature $\left(20-22{ }^{\circ} \mathrm{C}\right) .5,6$

\section{RESULTS}

\subsection{Microstructure characterization of the ADI sam- ples}

After the basic and additional heat treatment of the ADI samples, metallographic investigations were carried

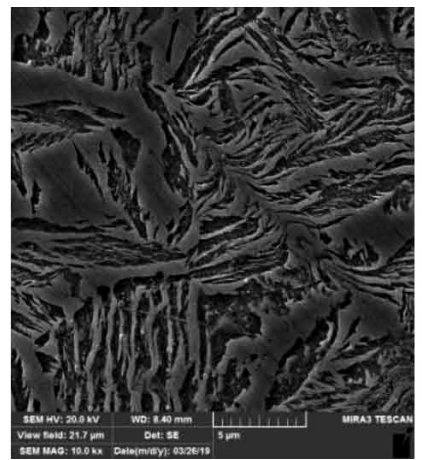

a)

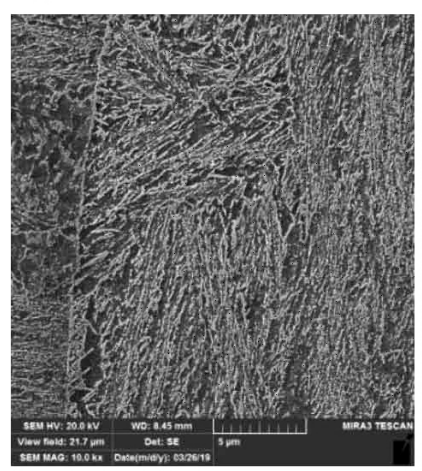

e)

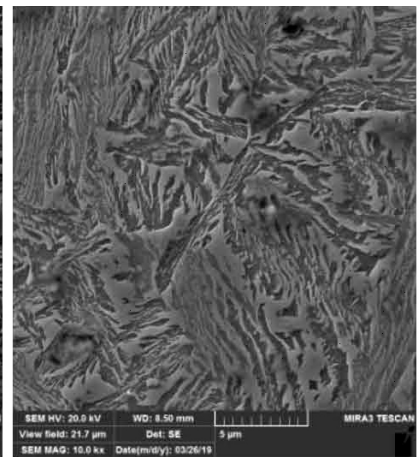

b)

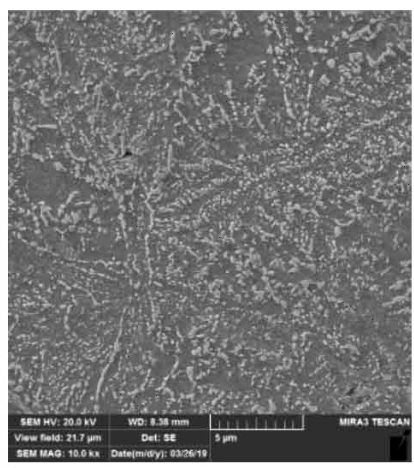

f)

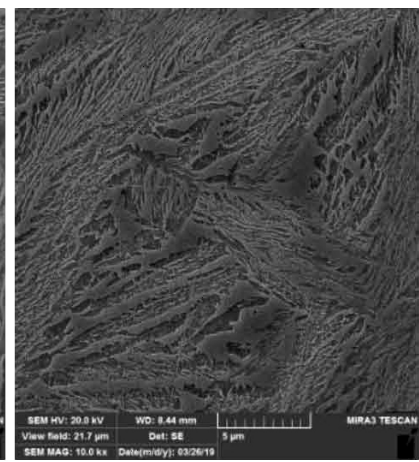

c)

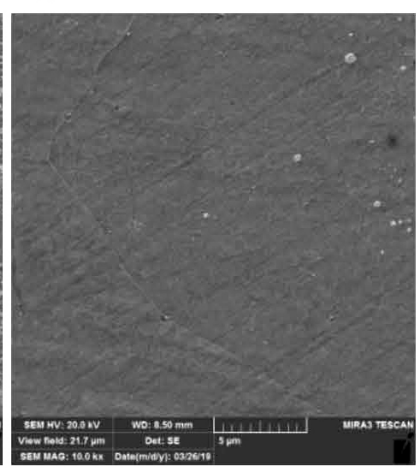

g)

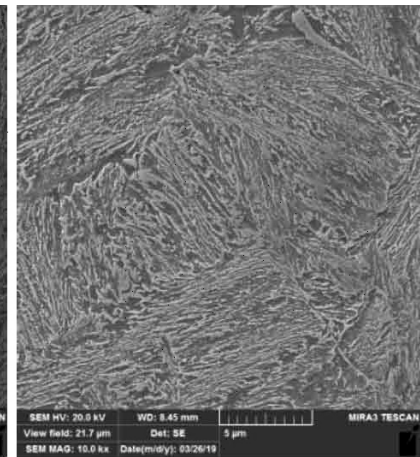

d)

Figure 5: Microstructures of the ADI samples (SEM, 10,000× mag., Nital etched): a) basic ADI sample, b) ADI sample reheated at $250{ }^{\circ} \mathrm{C}$ for $2 \mathrm{~h}, \mathrm{c}$ ) ADI sample reheated at $350{ }^{\circ} \mathrm{C}$ for $2 \mathrm{~h}$, d) ADI sample reheated at $450{ }^{\circ} \mathrm{C}$ for $2 \mathrm{~h}$, e) ADI sample reheated at $500{ }^{\circ} \mathrm{C}$ for $2 \mathrm{~h}$, f) ADI sample reheated at $600{ }^{\circ} \mathrm{C}$ for $2 \mathrm{~h}, \mathrm{~g}$ ) ADI sample reheated at $700{ }^{\circ} \mathrm{C}$ for $2 \mathrm{~h}$ 


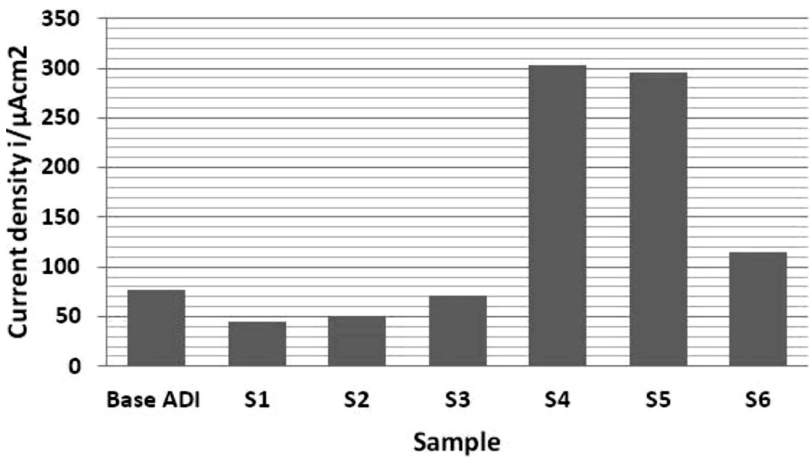

Figure 6: Current density of the tested samples

out. In Figure 5, SEM (scanning electron microscopy) microstructures of the used samples are presented.

\subsection{Corrosion test of the ADI samples}

Table 4 and Figure 5 present the results of the tests of the corrosion rate using the technique of Tafel curve extrapolation.

Table 4: Current density and open-circuit potential of the tested samples

\begin{tabular}{|c|c|c|}
\hline Sample & $\begin{array}{c}\text { Current density } i \\
\mu \mathrm{A} / \mathrm{cm}^{2}\end{array}$ & $\begin{array}{c}\text { Open circuit potential } \\
E(i=0) / \mathrm{mV}\end{array}$ \\
\hline Base ADI & $7.725 \cdot 10^{1}$ & $-467,18$ \\
\hline $\mathrm{S}_{1}$ & $4.491 \cdot 10^{1}$ & -473.08 \\
\hline $\mathrm{S}_{2}$ & $5.132 \cdot 10^{1}$ & -470.37 \\
\hline $\mathrm{S}_{3}$ & $7.038 \cdot 10^{1}$ & -471.19 \\
\hline $\mathrm{S}_{4}$ & $3.034 \cdot 10^{2}$ & -478.04 \\
\hline $\mathrm{S}_{5}$ & $2.958 \cdot 10^{2}$ & -483.66 \\
\hline $\mathrm{S}_{6}$ & $1.145 \cdot 10^{2}$ & -488.88 \\
\hline
\end{tabular}

\section{DISCUSSIONS}

After the heat treatment of ductile iron ADI, samples with ausferrite microstructures were produced. The resulting ausferrite microstructure was found to have a uniform distribution of a needle-shaped ferrite phase within the carbon-saturated austenite phase. The additional reheating of the ADI samples at different temperatures led to an ausferrite decomposition that is visible on Figure 5. With the increasing reheating temperature, the transformation rate of carbon-saturated austenite increases. Carbon-saturated austenite $\left(\gamma_{\mathrm{CS}}\right)$ transforms into ferrite and iron carbide according to Equation (1):

$$
\gamma_{\mathrm{CS}}=\alpha+\mathrm{Fe}_{3} \mathrm{C}
$$

Table 4 and Figure 6 show different corrosion properties of the treated ADI samples. The highest current density is found for ADI samples $\mathrm{S}_{4}$ and $\mathrm{S}_{5}$. An increase in the current density indicates a decrease in the corrosion resistance of the treated samples. There was no big difference in the open-circuit potential values for the observed samples. The samples with the increased level of the current density (samples $\mathrm{S}_{4}, \mathrm{~S}_{5}$ and $\mathrm{S}_{6}$ ) had lower values of the open-circuit potential.

Generally, several effects could be identified as the reasons for this behavior, but the decomposition of the ausferrite microstructure in the temperature region above $450{ }^{\circ} \mathrm{C}$ and the presence of the carbide phase in the microstructure were the most pronounced. In the temperature region near the eutectoid temperature, graphitization (decomposition of the iron carbides) occurred and it could be the reason for the decrease in the current density during the corrosion test of sample $S_{6}$.

\section{CONCLUSIONS}

The carried out investigation and analysis of the results of the experiments on the reheated ADI samples allow the following conclusions:

- The paths of the decomposition of austempered ductile iron, reheated up to $700{ }^{\circ} \mathrm{C}$ and its influence on the general corrosion behavior were recognized and summarized in Figure 5 and Table 4.

- The most intensive decomposition of the ausferrite microstructure was observed in the temperature region above $450{ }^{\circ} \mathrm{C}$.

- The decomposition of the ausferrite microstructure had a negative influence on the general corrosion behavior of the tested samples.

- The lowest corrosion resistance (the highest current density) was recorded for samples $S_{4}$ and $S_{5}$, presented in Table 4 and Figure 6.

\section{REFERENCES}

${ }^{1}$ J. R. Keough, Austempered Ductile Iron, Ductile Iron Society, Strongsville, Ohio, USA, 1998

${ }^{2}$ https://www.ductile.org/didata/Section4/4intro.htm, 29.08.2019

${ }^{3}$ European standard: EN 1564: 1997

${ }^{4}$ R. Rocha-Reséndez, J. A. Cabral-Miramontes, C. Gaona-Tiburcio, P. Zambrano-Robledo, F. Estupiñan-López, F. Almeraya Calderon, Proceedings of the Symposium of Aeronautical and Aerospace Processes, Materials and Industrial Applications, Springer International Publishing AG 2018, doi:10.1007/978-3-319-65611-3_7

${ }^{5}$ M. Janjić, H. Avdušinović, Z. Jurković, F. Bikić, S. Savićević, Influence of austempering heat treatment on mechanical and corrosion properties of ductile iron samples, Metallurgy, 55 (2016) 3, 325-328

${ }^{6}$ C. H. Hsu, J. K. Lu, K. L. Lai, M. L. Chen, Erosion and Corrosion Behaviors of ADI Deposited TiN/TiAlN Coatings by Cathodic Arc Evaporation, Materials Transaction, 46 (2005) 6, 1417-1424 